\title{
Communication
}

[Comunicação]

\section{Pectus carinatum in a dog}

[Pectus carinatum em um cão]

\author{
D.B. Souza ${ }^{1}$, P.S.C. Andrade Júnior ${ }^{2}$, C.M.A. Mariano ${ }^{2}$, F.S. Costa ${ }^{3}$, E.J. Abílio ${ }^{4}$
}

\author{
${ }^{1}$ Aluno de pós-graduação - UERJ - Rio de Janeiro, RJ \\ ${ }^{2}$ Aluno de pós-graduação - CCTA-UENF - Campos dos Goytacazes, RJ \\ ${ }^{3}$ Centro de Ciências Agrárias - UFES - Alegre, ES \\ ${ }^{4}$ Centro de Ciências e Tecnologias Agropecuárias - UENF - Campos dos Goytacazes, RJ
}

Deformities of the anterior thorax wall, named Pectus, are commonly observed in children and teenagers (Beirão, 1999); however, they are considered rare in small animals (Orton, 1998). Two types of deformities are known: the Pectus excavatum (PE) and Pectus carinatum (PC). PE is a dorsal to ventral narrowing of the thorax, also known as funnel chest (Fossum, 2002), whereas PC is a ventral protrusion of the sternum, also known as Pectus galinatum or pigeon breast (Cardenal, 1954). There is no clear known etiology for either type of sternum congenital deformity in humans and animals (Haje, 1995; Ellison and Halling 2004; Frey et al., 2006).

Some papers describe the PE and its treatment in small animals (Sturgess et al., 1997; Crigel and Moissonnier, 2005; Risselada et al., 2006) and although Fossum (2002) described the PC as an abnormality which occurs much less frequently than $\mathrm{PE}$, no record has been found in either dogs or cats concerning PC.

According to Haje (1995) and Frey et al. (2006), in studies with humans, PC was more commonly found than PE (74\% vs. 26\%). Interestingly, it occurred four times more frequently in males than in females and was often associated with other disorders (Marfan's syndrome, Oteogenesis imperfecta, scoliosis, and others). Surgery has been the major treatment for PC in humans, although non-operative treatments presented good results (Haje, 1995; Beirão, 1999; Frey et al., 2006).

This paper describes the case of a dog which was born from a consanguineous cross-mating and was diagnosed with Pectus carinatum among several other congenital diseases.

Recebido em 26 de maio de 2008

Aceito em 15 de outubro de 2008

E-mail: diogo@uenf.br
A five-month-old male Miniature Pinscher, was referred to the Veterinary Hospital at the Universidade Estadual do Norte Fluminense to be evaluated for several congenital malformations. Its owner had acquired it four months earlier and had noted several abnormalities, such as chest deformity, bad dental occlusion, bad limb angulations with ambulation difficulties, absence of testicles in the scrotum, and an umbilical hernia.

This dog was born from a consanguineous crossmating of a son and its mother, which whelped four puppies. One of them died a few days after its birth, the second one did not show any congenital abnormalities, and the third one presented many congenital defects just as the present case. The dog in question was also reported to tire easily and presented breathing difficulties when exercised. The limb deformities became less severe since it was adquired by new owner.

The sternum of the dog was evidently protruded ventrally on its distal portion, forming a step between the thorax and abdomen as seen in Fig. 1. Both testicles were found at the inguinal region, thus confirming the bilateral inguinal cryptorchidism. In addition, other abnormalities were noted, such as: an umbilical hernia, anteversion of anterior limbs, genu valgo and bad dental occlusion with the mandible frontally projected to the maxilla. This dog also presented a heart rate of 126 beats per minute, a respiratory rate of 11 breaths per minute, rectal temperature of $39^{\circ} \mathrm{C}$, weight of two kilograms, normal auscultation of heart and lungs, as well a good general state of health and behavior. 


\section{Pectus carinatum in a dog}

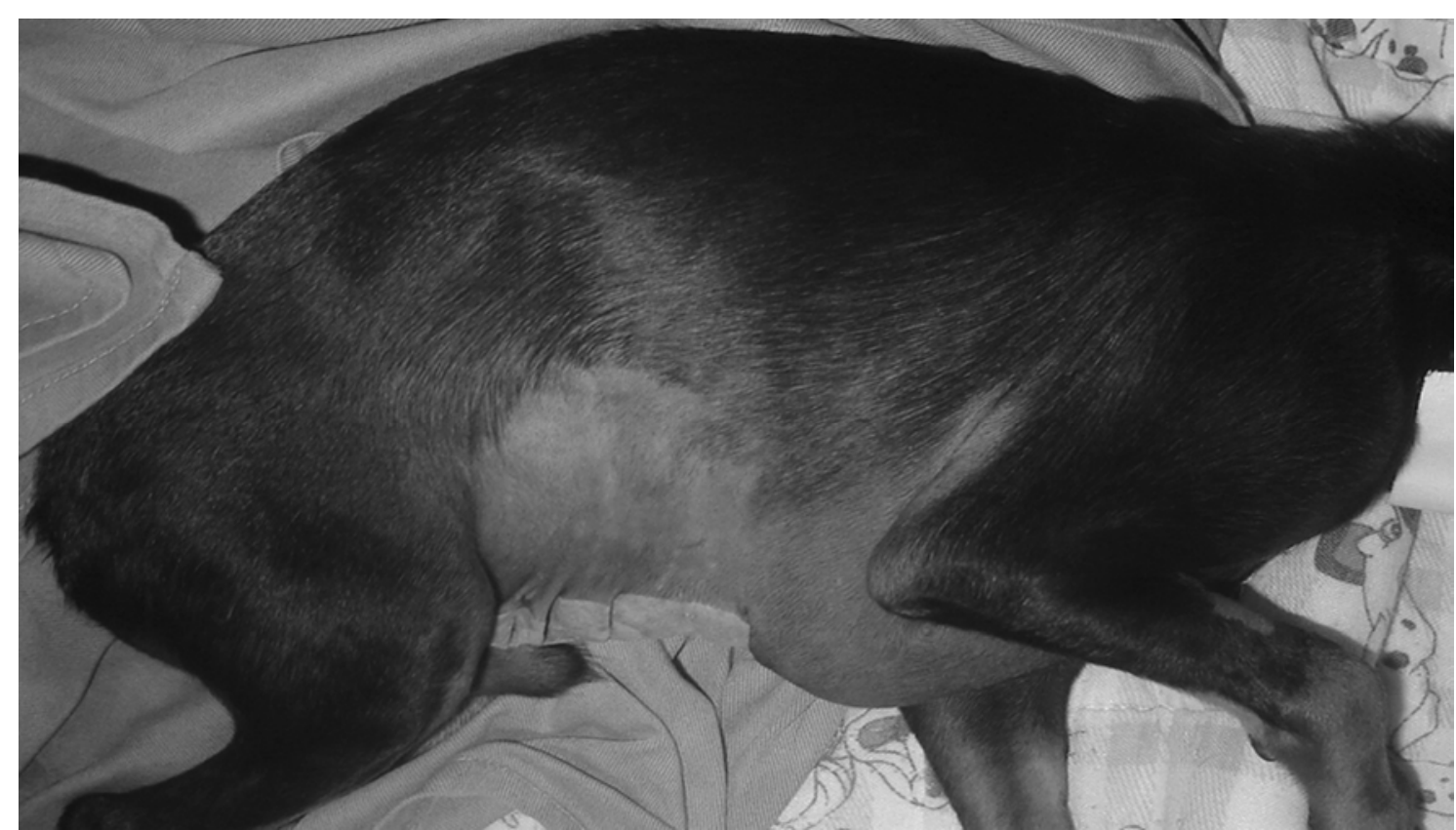

Figure 1. Dog with Pectus carinatum. It was noted that a step is formed between the thoracic and abdominal ventral wall.

Thoracic radiographs and blood analysis were performed. The thoracic radiography showed a marked ventral protrusion of the distal part of the sternum (Fig. 2). Thoracic radiographic measurements were carried out according to

Fossum et al. (1989), and the obtained results were: 0.89 for the frontosagital index and 16.6 for the vertebral index (reference ranges, 0.7-13 and 12.6-18.8, respectively).

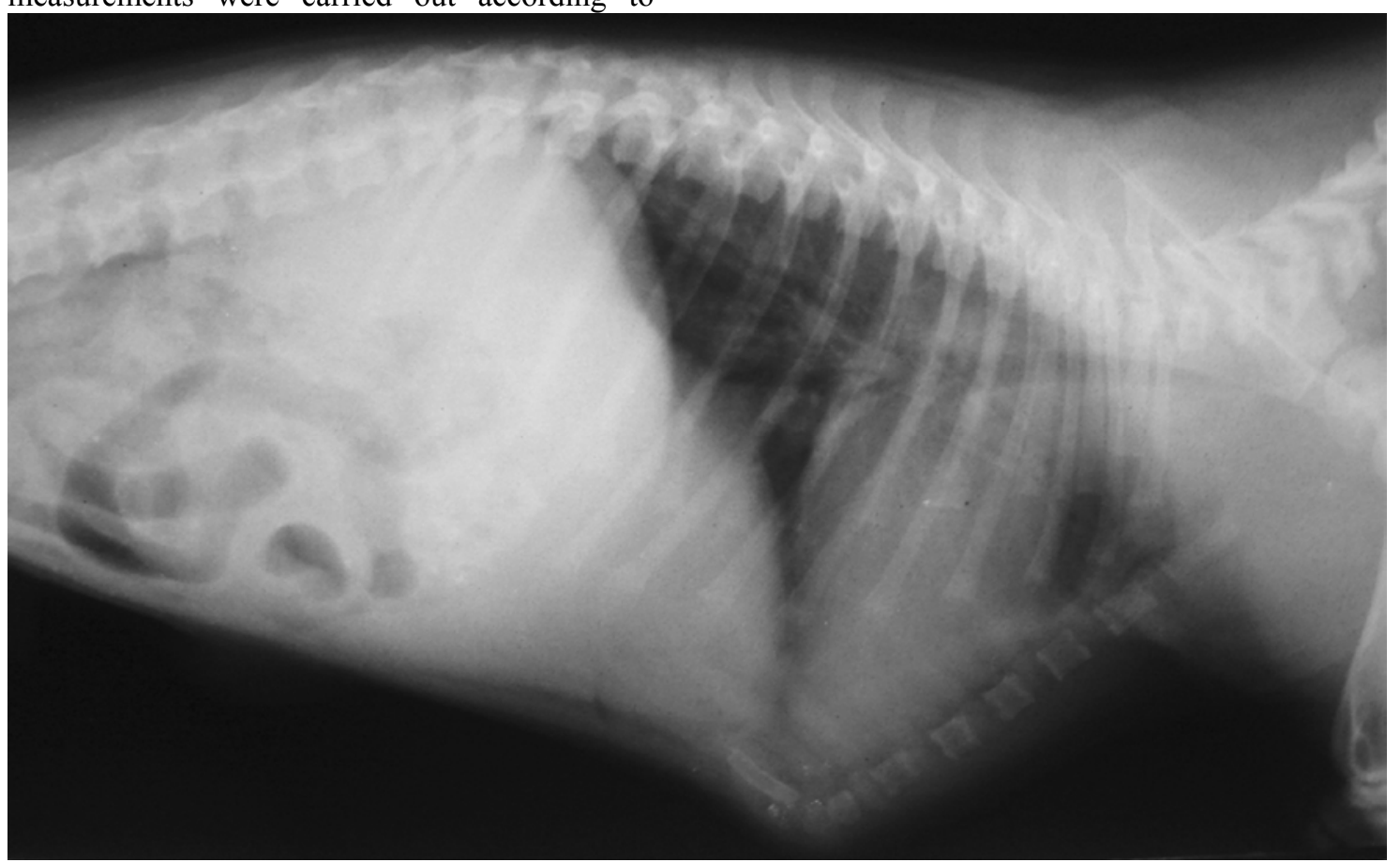

Figure 2. Radiography showing ventral protrusion of the distal part of the sternum, in a dog with Pectus carinatum. 
The chemical pathology tests showed microcitosis (packed cell volume $31.4 \%$ [reference range, 37-55\%], hemoglobin $10.6 \mathrm{~g} / \mathrm{dL}$ [reference range, $12-18 \mathrm{~g} / \mathrm{dL}$ ], mean cell volume 50.9fl [reference range, 60-77fl]), mild hypoglycemia $(68 \mathrm{mg} / \mathrm{dL}$ [reference range, 70 $110 \mathrm{mg} / \mathrm{dL}]$ ), and an increase in alanine transaminase $(33.83 \mathrm{UI} / \mathrm{L}$ [reference range, 4.824UI/L]).

Surgical correction of the umbilical hernia and cryptorchidism (bilateral orchiectomy) were performed. It was recommended to keep the dog in a place with a hard floor and to submit it to regular short walks on a sandy floor in order to decrease walking difficulties and angular deformities.

After the surgeries, a compressive splint was dorsally applied on the sternum of the dog, under anesthesia. However, because of this compression, the dog became very dyspneic, and cyanotic; thus, requiring the splint to be removed and for oxygen to be administered via a face mask. The cyanosis and the dyspnea were overcome in a few minutes after the removal of the splint and the administration of oxygen. In view of these findings, it was decided do not use the thoracic splint.

At the time of post-operative revision and suture removal, the animal exhibited conditions of good general health and the owner was satisfied with the treatments. He did not agree to any other tentative for sternum correction. After four months, the owner was contacted and reported the obit of the animal a few weeks previously due to a gastrointestinal infection. The angular deformities of the limbs were also reported to be significantly better, although moderate dyspnea was present after exercising, but which did not interfere with its life quality, in the opinion of the owner.

Pectus deformities are malformations that affect both humans and animals, causing cardiopulmonary compromise. Although PE, the most common type of the disease in small animals, usually causes severe dyspnea (Crigel and Moissonnier, 2005), the PC studied here demonstrated respiratory distress only when the animal was under exercise, which according to its owner was well-tolerated. Possibly, the protrusion of the sternum caused respiratory compromise with lower clinical significance against the narrowing of the thorax.

Surgery for PC is the first option in humans, but more recently some authors have advocated a conservative treatment with the use of orthotic bracing that provides continued ventro-dorsal sternal compression with success (Haje, 1995; Beirão, 1999; Frey et al., 2006). According to these authors, the non-operative approach to PC is a safe, effective, and cheaper option of treatment. Unfortunaly, in the present case, the compressive splint caused severe dyspnea, probably due to impairment of the thoracic expansion and was promptly removed. After this experience, the owner did not agree to another splint attempt, arguing that the chest deformity and the difficulties related to exercise were tolerable.

According to Haje (1995), PC can be classified as superior, inferior, or lateral, based on the anatomical localization of the protrusion. Other classification proposals are based on correlation to other diseases, when idiopathic or pure Pectus are those with no relationship to osseous affections. Pathologic Pectus is related to osseous affections, whereas iatrogenic Pectus are those caused by surgical lesion of the growing plates of the sternum (Haje, 1995). Following these classifications, this case can be considered as an inferior, pathologic PC.

No definitive etiology of PC has been established for human; however, the increased incidence of positive familiar history $(25 \%)$ of chest wall deformity suggests a genetic linkage (Frey et al., 2006). In this case, a consanguineous crossmating could be a possible cause of the congenital diseases, including its chest deformity.

An objective assessment of PE deformity in small animals was proposed by measuring the frontosagital and vertebral indexes (Fossum et al., 1989). These indexes were calculated based on the ratio of some measurements of the thorax and vertebrae in thoracic radiographs. It has also been proposed that these indexes may aid the classification of mild, moderate, or severe PE. When these indexes were applied in this PC case, the results were within the normal ranges, although subjective evaluation of radioghraphs showed a marked PC. These indexes should be 
tested on more PC cases, beacuse at present, they are not useful for the classification of PC deformities in small animals.

Keywords: dog, Pectus deformity, congenital disorder, Pectus carinatum

\section{RESUMO}

Descreve-se o atendimento de um cão macho de cinco meses de idade, apresentando diversas malformações congênitas, incluindo uma protrusão ventral da parte distal do externo, que foi diagnosticada como Pectus carinatum tendo por base os achados clínicos e radiográficos.

Palavras-chave: cão, deformidade Pectus; anomalia congênita, Pectus carinatum

\section{REFERENCES}

BEIRÃO, M.E. Tratamento conservador de Pectus carinatum com uso de órtese. Rev. Bras. Ortop., v.34, p.575-578, 1999.

CARDENAL, L. Diccionario termilogico de ciencias medicas. 5.ed. Barcelona: Salvat, 1954. $1378 \mathrm{p}$.

CRIGEL, M.H.; MOISSONNIER, P. Pectus excavatum surgically repaired using sternum realignment and splint techniques in a young cat. J. Small Anim. Pract., v.46, p.352-356, 2005.
ELliSON, G.; HALLING, K.B. Atypical Pectus excavatum in two Welsh terrier littermates. $J$. Small Anim. Pract., v.45, p.311-314, 2004.

FOSSUM, T.W. Small animal surgery. 2.ed. St. Louis: Mosby, 2002. p.760-787.

FOSSUM, T.W.; BOUDRIEAU, R.J.; HOBSON, H.P. Pectus excavatum in 8 dogs and 6 cats. J. Anim. Hosp. Assoc., v.25, p.595-605, 1989.

FREY, A.S.; GARCIA, V.F.; BROWN, R.L. et al. Nonoperative manegement of Pectus carinatum. J. Pediatr. Surg., v.41, p.40-45, 2006.

HAJE, S.A. Deformidades Pectus: novos conceitos e abordagem ortopédica. Rev. Bras. Ortop., v.30, p.75-79, 1995.

ORTON, C. Parede torácica. In: SLATTER, D. 2.ed. Manual de cirurgia de pequenos animais. São Paulo: Manole, 1998. p.456-468.

RISSELADA, M.; DE ROOSTER, H.; LIUTI, T. et al. Use of internal splinting to realign a noncompliant sternum in a cat with Pectus excavatum. J. Anim. Vet. Med. Assoc., v.228, p.1047-1052, 2006.

STURGESS, G.P.; WATERS, L.; GRUFFYDDJONES, T.J. et al. Investigation of the association between whole blood and tissue taurine levels and the development of thoracic deformities in neonatal Burmese kittens. Vet. Rec., v.141, p.566-570, 1997. 